\author{
Robert Faracik \\ Uniwersytet Jagielloński \\ Wydział Geografii i Geologii \\ Instytut Geografii i Gospodarki Przestrzennej \\ Zakład Gospodarki Turystycznej i Uzdrowiskowej \\ robert.faracik@uj.edu.pl
}

\title{
SANDOMIERZ - MIASTO HISTORYCZNE JAKO OŚRODEK TURYSTYKI
}

\begin{abstract}
Abstrakt: Sandomierz należy do najstarszych polskich miast, a jego początki sięgają okresu wczesnopiastowskiego. Tysiącletnia historia miasta uwidacznia się w zachowanym po dziś dzień zabytkowym zespole urbanistyczno-architektonicznym, który szczęśliwie przetrwał pożogi wojenne. Dzisiejszy obraz "turystycznego" Sandomierza nieodzownie łączy się z realizowanym w plenerach miasta serialem "Ojciec Mateusz”, który stał się niezwykle ważnym środkiem promocji walorów turystycznych miasta oraz kreowania jego wizerunku jako przyjemnego i przychylnego dla turystów miejsca. Potwierdza to rozwój zarówno infrastruktury turystycznej, jak i wyraźny wzrost ruchu turystycznego, jaki obserwuje się po 2008 r. Miasto ma do zaoferowania także wiele innych walorów, które stopniowo stają się przesłanką rozwoju nowych form turystyki.
\end{abstract}

Słowa kluczowe: Sandomierz, miasto historyczne, turystyka.

\section{WSTĘP}

Od początków nowożytnej turystyki miasta przyciągają podróżnych zarówno bogactwem swojej historycznej i kulturowej spuścizny, jak i możliwością spędzenia czasu na konsumpcji oferowanych przez nie usług. Widoczne jest to m.in. na przykładzie zjawiska grand tour, które pojawiło się wraz $\mathrm{z}$ renesansowymi prądami Europy końca XVI w., a nasilił się w wiekach następnych. Wówczas to m.in. młodzi Anglicy podążali w kierunku południowej Europy odwiedzając kolejne miejsca związane zarówno $\mathrm{z}$ historią starożytną, jak i późniejszymi epokami historycznymi i artystycznymi. Na trasie ich podróży znajdowały się m.in.: Paryż, Wenecja, Florencja i Rzym, jak i wiele mniejszych miast i miasteczek, w których zachowały się ślady przeszłości. W ślad za Anglikami podążyli inni Europejczycy, w tym Niemcy, Rosjanie i Francuzi, a także Polacy, których ojczyzna w XIX w. znajdowała się pod zaborami.

Tym sposobem uksztaltował się swoisty kanon miasta historycznego jako ośrodka, do którego przybywają podróżni zwabieni jego pięknem, będącym wyrazem zarówno samego faktu zabytkowości, jak i w wielu wypadkach szczególnych walorów krajobrazowych wynikających z wzajemnych relacji miasta z przyrodą (m.in. formy ukształtowania powierzchni, rzeki, kompleksy roślinne, wybrzeże morskie, surowce mineralne). Swoiste więzi łączące miasto z przyrodą uwidaczniały się przede wszystkim $\mathrm{w}$ okresie antycznym, w miastach średniowiecznych i renesansowych (m.in. w aspekcie obronności i podstaw rozwoju gospodarczego) oraz w epoce baroku i klasycyz$\mathrm{mu}$ (m.in. walory estetyczno-krajobrazowe). W tym ujęciu czasowym powstałe i rozwijające się wówczas miasta określa się często mianem miast historycznych, w odróżnieniu od ośrodków rozwijających się już według nowego paradygmatu miasta nowoczesnego, powstałego na potrzeby zmieniającego się w szybkim tempie społeczeństwa kapitalistycznego.

Miasto jako specyficzny twór trwający w czasie, podlegający zmianom oraz kształtujący się i kształtowany $\mathrm{w}$ celu pełnienia określonych funkcji z punktu widzenia jego mieszkańców i użytkowników, zatracał stopniowo swoją "historyczność". Proces ten wspomagany był innymi czynnikami, takimi jak np.: katastrofy naturalne, wojny czy też decyzje polityczne. Dlatego też różny jest stopień zachowania zabytkowej substancji w poszczególnych miastach i różny jest stosunek do niej zarówno współczesnych mieszkańców, jak 
i decydentów odpowiedzialnych za kształtowanie wizji miasta w przyszłości.

Należy wyraźnie zaznaczyć, że terminem „miasto historyczne" określane są różne jednostki strukturalne. Stosuje się go zarówno w odniesieniu do całego organizmu miejskiego, jak i tylko do określonej jego części, gdzie zachował się zabytkowy układ urbanistyczno-architektoniczny, niejednokrotnie związany bezpośrednio $\mathrm{z}$ początkami miasta (nazywany często dzielnicą staromiejską). Przykładowo, mówiąc o Krakowie jako mieście historycznym można mieć na uwadze całe miasto $w$ granicach administracyjnych (poddając analizie szeroko rozumiane wątki historyczne na całym jego obszarze), jak i wyłącznie zabytkowe centrum, którego zewnętrzne granice są traktowane dość płynnie w zależności od stosownego kontekstu.

Analizując zagadnienie relacji miasta historycznego i turystyki szczególną rolę odgrywają prace G. Ashwortha (ASHWORTH, TUNBRIDGE 1990, ASHWORTH 1993), którego badania i publikacje stanowią podstawę wielu opracowań dotyczących tego zagadnienia. Należy jednak zwrócić uwagę, że w ujęciu tego autora termin "miasto historyczne" jest stosowane w dynamicznym ujęciu relacji współczesnego człowieka do historii miasta. Jest opisywane jako drugie stadium w procesie przekształcania się miasta "starego" wiekiem w miasto dziedzictwa, które analizowane jest w dużej mierze jako oferowany turystom na sprzedaż, podlegający prawom rynku produkt turystyczny. Istotnym w tym względzie procesem jest tzw. planowanie dziedzictwa. Nie każde, nawet bardzo "stare” miasto w tym ujęciu jest miastem historycznym.

Dzieje miast Polski sięgają wczesnego średniowiecza, a ich początków należy upatrywać w grodach piastowskich, których relikty datowane są na X-XI w. Większość współczesnych miast polskich ma średniowieczne korzenie, przy czym w wielu przypadkach "historyczna” dzielnica zachowała się w formie układu urbanistycznego przy nikłym udziale substancji zabytkowej, co w dużej mierze jest wynikiem zniszczeń podczas I i II wojny światowej. Najlepiej zachowane zespoły urbanistyczno-architektoniczne zostały uznane za światowe dziedzictwo (UNESCO), jak miało to miejsce w przypadku: Krakowa, Warszawy (miasto zrekonstruowane), Zamościa i Torunia.

Jednym z najlepiej zachowanych zespołów staromiejskich odznacza się Sandomierz (ok. 25 tys. mieszkańców w 2015 r.). Stare Miasto (Starówka) leży na wysokiej skarpie, a właściwie na pokrytym lessem wzgórzu w formie wydłużonego cypla, oddzielonego po dziś dzień od reszty miasta głębokimi wąwozami i doliną Wisły. Powoduje to, że odznacza się ono nadzwyczaj wysokimi walorami krajobrazowymi. Sylweta miasta szczególnie dobrze widoczna jest od strony Wisły, a tworzą ją kolejno następujące po sobie

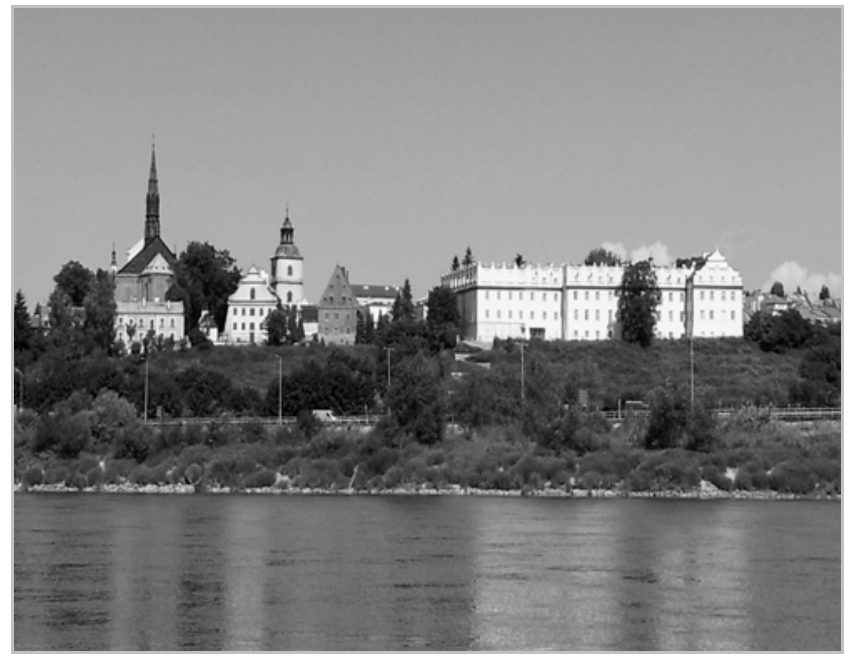

Fot. 1. Sandomierz - panorama miasta od strony Wisły (fot. R. Faracik)

dominanty, wzbogacające poziomą kompozycję całości zespołu urbanistycznego (fot. 1). Ta izolacja wzniesienia spowodowała także zachowanie jego wyjatkowego, historycznego charakteru. Wąwozy lessowe oraz unikatowy obszar Gór Pieprzowych dodatkowo wzbogacają walory turystyczne miasta (PAŁYS, WEGOREK 1998, CZARNECKI 1996). Ośrodkiem turystycznym miasto to stało się już na przełomie XIX i XX w., o czym świadczą wydawane już wówczas przewodniki i inne publikacje. Celem niniejszego artykułu jest ukazanie roli dzielnicy staromiejskiej Sandomierza w rozwoju miasta jako ośrodka turystyki.

\section{STARE MIASTO W STRUKTURZE PRZESTRZENNEJ WSPÓŁCZESNEGO SANDOMIERZA}

W wyniku trwających około 1000 lat przekształceń w obrębie systemu osadniczego Sandomierza (KALINOWSKI i in. 1956, KALINOWSKI 1986, FLOREK 2005) ukształtował się układ (rys. 1), którego kluczowym elementem jest dzisiejsze Stare Miasto (rys. $1 \mathrm{nr} 4$ ). Lokowane było w 1286 r. przez księcia Leszka Czarnego (po ostatecznym zniszczeniu wcześniejszego gro-du podczas najazdów tatarskich w 1259/1260 r.), a następnie powiększone i umocnione przez Kazimierza Wielkiego. Jego integralną częścią są dawne oddzielne wzniesienia (nr 2b), na których zlokalizowane były wczesnośredniowieczne osady (okolice dzisiejszej katedry oraz Collegium Gostomianum). Z osadac w okolicach późniejszego kościoła pw. św. Jakuba (nr 2a) tworzyły one wraz $\mathrm{z}$ obronnym grodem na wzgórzu zamkowym (1), zespół najstarszego osadnictwa na obszarze dzisiejszego Sandomierza. Do połowy 
XIII w. miasto rozwijało się w obrębie lessowych wzgórz staromiejskich (nr 3), a świadkiem tego okresu są zachowane dwie świątynie - pw. św. Jakuba oraz św. Pawła. Współcześnie ta część miasta (pierwotne Stare Miasto) jest w dużej mierze „oazą" zieleni, z zachowanymi wąwozami lessowymi (m.in. św. Królowej Jadwigi czy Piszczele - zamieniony na park i teren wypoczynkowy). Do dzisiaj wzgórze z zamkiem jest naturalnym zwornikiem obu części miasta. Przedłużeniem Starówki poza mury średniowiecznego miasta jest część ukształtowana głównie w XVII w. u wylotu dróg łączących Sandomierz z Opatowem i Zawichostem (nr 5). Zlokalizowano tam dwa zespoły klasztorne, a dalsza rozbudowa miasta pociągnęła rozwój osadnictwa na obszarze tzw. Przedmieść: Opatowskiego i Zawichojskiego.

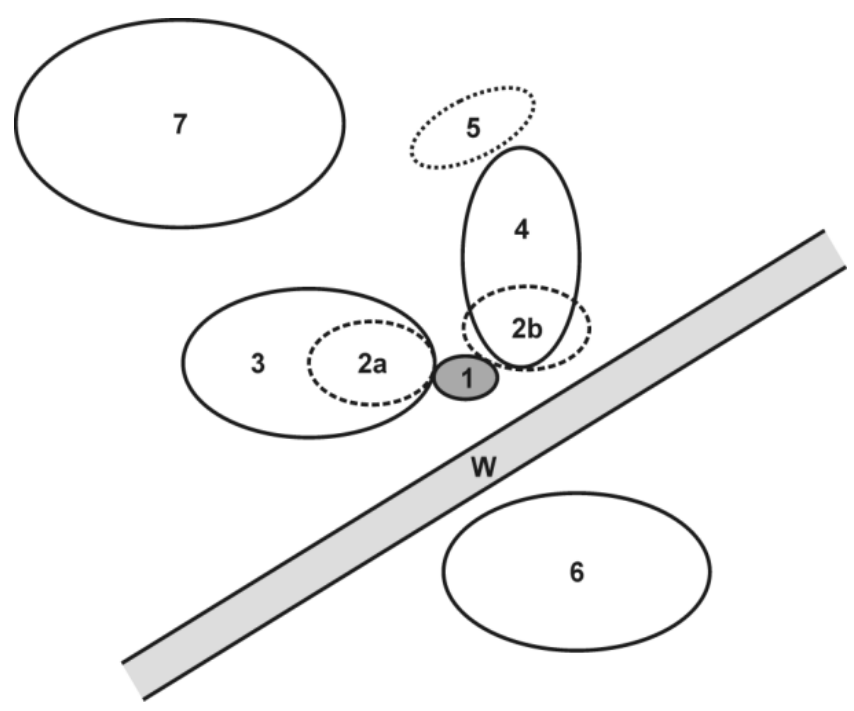

Rys. 1. Schemat układu osadniczego współczesnego Sandomierza

1 - wzgórze zamkowe, 2a - wzgórze świętojakubskie, $2 \mathrm{~b}$ - wzgórze kolegiackie i okolice Collegium Gostomianum, 3 - Stare Miasto do najazdu tatarskiego, 4 - miasto lokacyjne w obrębie wzgórza miejskiego, 5 - Przedmieście Opatowskie, 6 - prawobrzeżna część miasta, 7 - dzielnice mieszkaniowe (po 1945 r.), W - Wisła

Źródło: opracowanie własne

Istotna zmiana w strukturze urbanistycznej miasta zaznaczyła się dopiero w XX w. wraz z rozwojem Sandomierza jako ośrodka administracyjno-ekonomicznego planowanego COP-u w latach 30 . XX w. i przyłączeniem do miasta w 1938 r. terenów na prawym brzegu Wisły (6) (MYJAK 2013) oraz lokalizacją zakładów przemysłowych $\mathrm{w}$ dobie industrializacji okresu socjalistycznego i budową zaplecza mieszkaniowo-usługowego (nr 6, 7). Zachowanie zabytkowej dzielnicy śródmiejskiej w obrębie izolowanego wzniesienia ochroniło ją od bezpośrednich wpływów zarówno funkcji przemysłowej, jak i mieszkaniowej.

\section{ZNISZCZENIA W OBRĘBIE STAREGO MIASTA I ZAPOBIEGANIE ICH SKUTKOM}

Wraz ze stopniowym upadkiem miasta, który rozpoczął się w połowie XVII w., zaniedbywane budowle popadały $\mathrm{w}$ ruinę, a kolejne zbrojne starcia i wojny (w czasie zaborów Sandomierz był miastem przygranicznym) przyczyniały się do dalszych zniszczeń. Szczególnie nasilenie degradacji w obrębie Starego Miasta miało miejsce w XIX w. Prowincjonalne wówczas miasto, pozbawione szerszych perspektyw rozwoju, a co za tym idzie braku inwestycji, zostało postawione przed faktem potrzeby reorganizacji jego struktury oraz przebudowy zużytej już infrastruktury. Stan zniszczenia Starego Miasta potęgował fakt częstych katastrof budowlanych, spowodowanych osuwaniem się skarpy oraz zapadaniem się podziemnych korytarzy i magazynów. Sprzyjała temu budowa geologiczna wzgórz sandomierskich, gdyż przez pokrywającą je warstwę lessów infiltrowała woda, pochodząca zarówno z opadów, jak i nieszczelnych instalacji wodnych oraz kanalizacyjnych. Na szczęście realizacja tych projektów zakończyła się rozbiórką zniszczonych dość mocno murów miejskich i niektórych bardzo już zdegradowanych budynków (np. ruiny kościoła św. Piotra). Część miasta uległa zniszczeniom podczas działań I wojny światowej. Na szczęście Starówka nie ucierpiała podczas walk na przyczółku baranowsko-sandomierskim w lipcu i sierpniu 1944 r. i ocalała z pożogi II wojny światowej.

W drugiej połowie XX w. coraz bardziej dotkliwie odczuwane były zniszczenia w wyniku zapadania się gruntu i osypywania się skarpy. Postanowiono kompleksowo rozwiązać ten problem, oddając pole do działania pracownikom naukowym AGH w Krakowie. Rozpoczęte na początku lat 60 . XX w. prace pod kierunkiem prof. Zbigniewa Strzeleckiego pozwoliły poznać dokładnie geologię wzgórza miejskiego oraz zidentyfikować przyczyny zagrożeń. Sama akcja ratownicza rozpoczęła się w 1964 r., a znaczną część robót wykonywali górnicy z Zakładów Robót Górniczych „Północ” w Bytomiu. Pierwszy etap prac zakończony został w 1980 r. wraz z obchodami millenium Sandomierza. Jednym z dodatkowych rozwiązań zaproponowanych przez pracujących nad projektem naukowców było opracowanie podziemnej trasy turystycznej w obrębie odkrytych ciekawych korytarzy pod sandomierskim rynkiem. Trasę o długości około 470 m oddano do użytku 10 grudnia 1977 r. Składają się na nią 34 wyrobiska, którym nadano nazwy nawiązujące do dziejów i legend Sandomierza (MIKOŚ, CHMURA, TAJDUŚ 2013). Wiedzie ona spod Kamienicy Oleśnickich pod budynek ratusza i należy do największych atrakcji turystycznych miasta. 


\section{ZABYTKI STAREGO MIASTA JAKO WALOR TURYSTYCZNY SANDOMIERZA}

Cały obszar zabytkowego zespołu urbanistyczno-architektonicznego Sandomierza (rys. 2) zajmuje powierzchnię około 40 ha, z czego 16 ha przypada na dzisiejszą Starówkę (miasto lokacyjne). Skupiają się tutaj właściwie wszystkie zabytki, wśród których wyróżniają się przede wszystkim obiekty sakralne. Należą do nich m.in.: zespół katedralny (XIV-XIX w.), kościół pw. św. Jakuba (1226, XIV/XV w.) wraz ze skrzydłem klasztoru dominikanów (XIII w.), kościół pw. Nawrócenia św. Pawła (1. poł. XV w.), zespół klasztorny benedyktynek z kościołem pw. św. Michała (XVII-XVIII) (fot. 2), zespół klasztorny reformatów z kościołem pw. św. Józefa (1679-1690, XVIII w.) oraz dawny zespó1 szpitalny z kościołem pw. Świętego Ducha (XV w., XVIII w.).

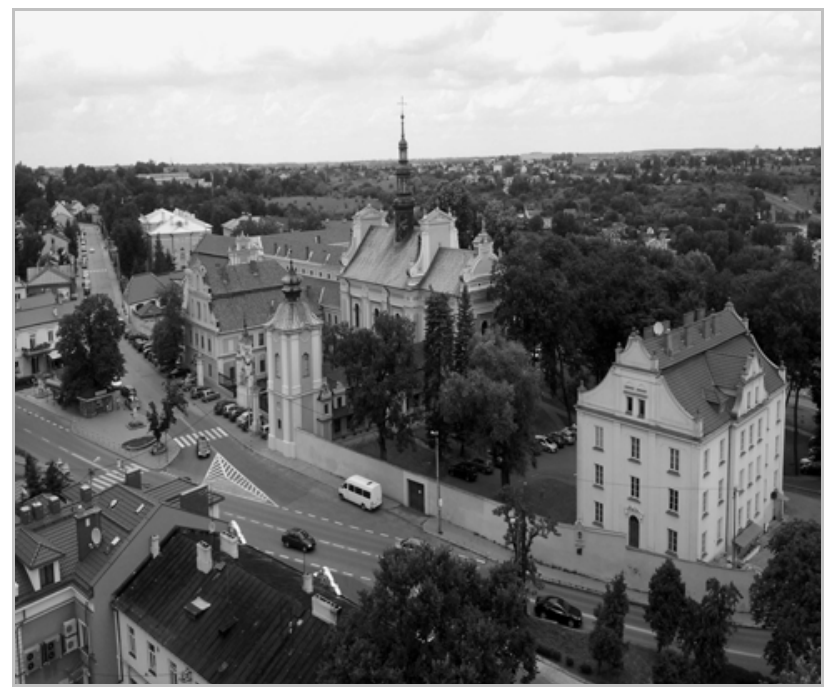

Fot. 2. Zespół klasztorny benedyktynek z kościołem pw. św. Michała - widok z Bramy Opatowskiej (fot. R. Faracik)

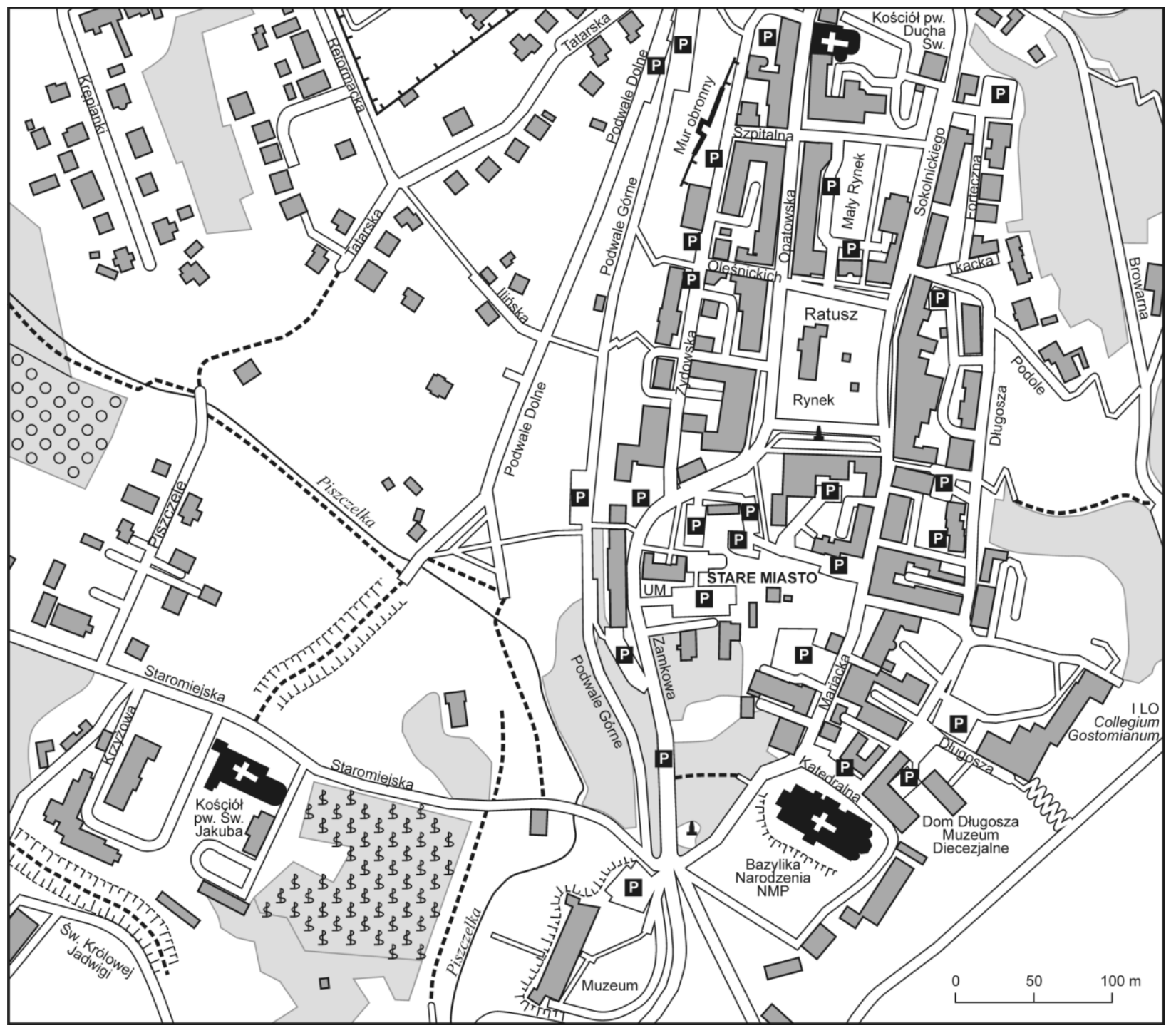

Rys. 2. Plan Starego Miasta w Sandomierzu Źródło: www.mapy.cz 


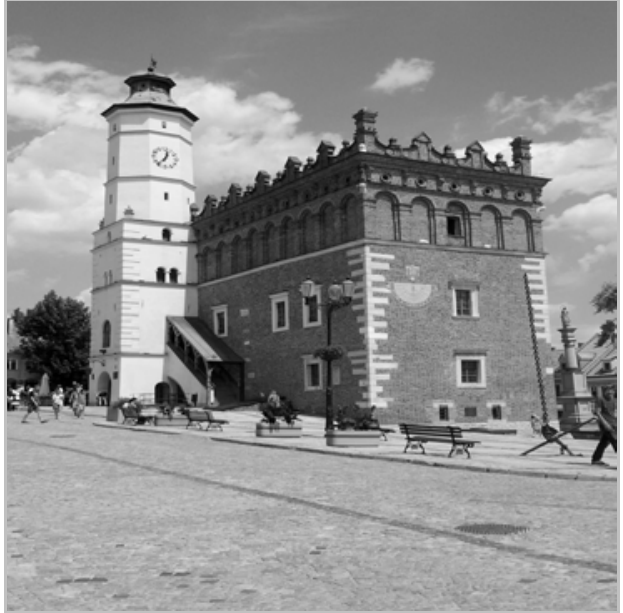

Fot. 3. Ratusz w Sandomierzu

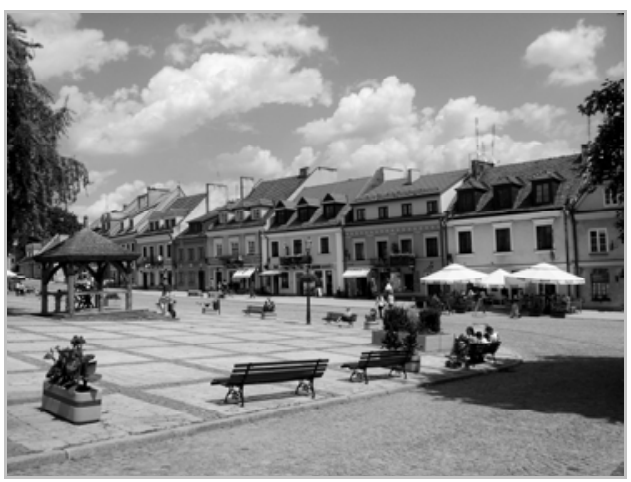

Fot. 5. Rynek w Sandomierzu - pierzeja wschodnia

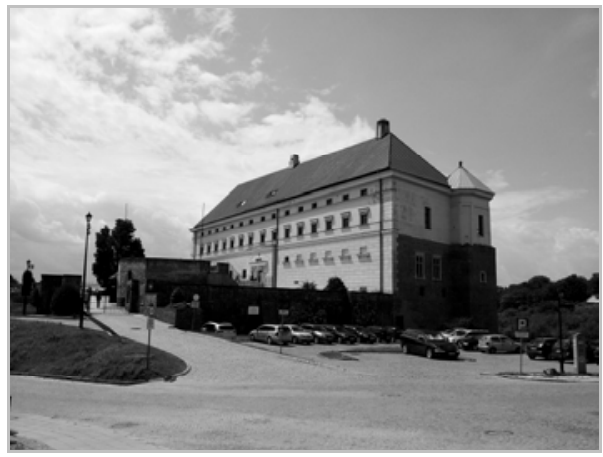

Fot. 7. Zamek w Sandomierzu

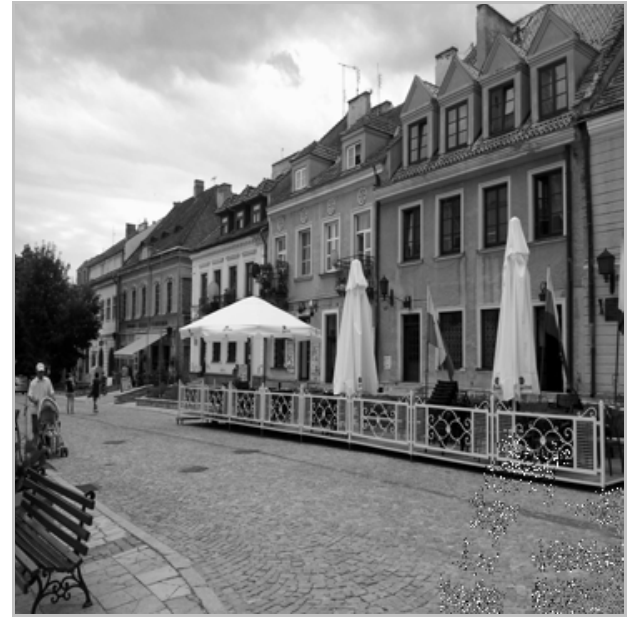

Fot. 4. Rynek w Sandomierzu - pierzeja zachodnia

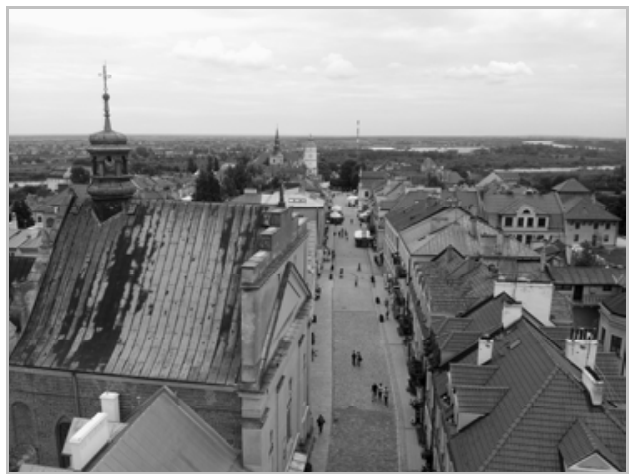

Fot. 6. Ulica Opatowska - widok z tarasu widokowego na Bramie Opatowskiej

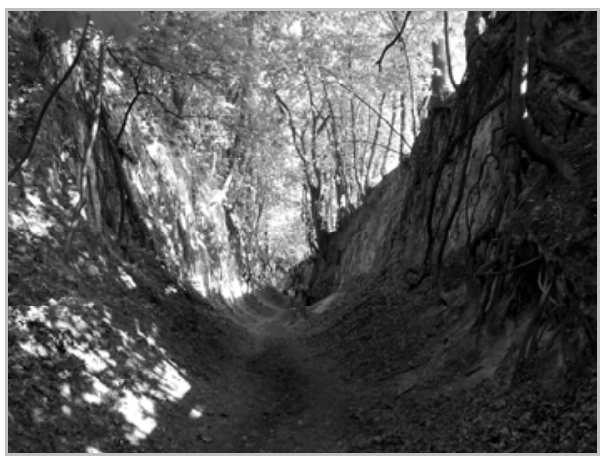

Fot. 8. Lessowy Wąwóz św. Królowej Jadwigi

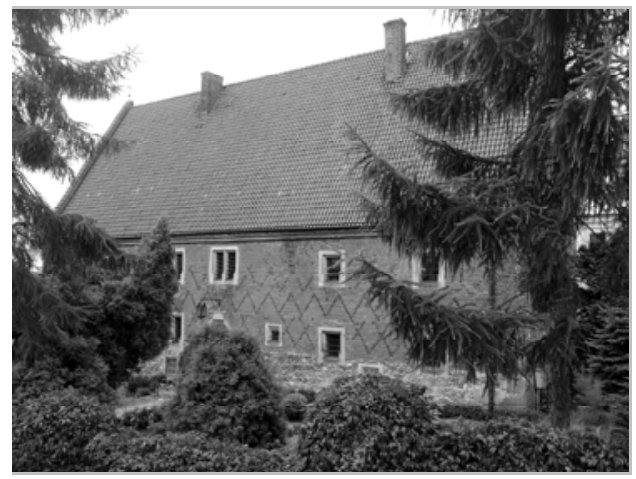

Fot. 9. Dom Długosza

(fot. 3-9 autor) 
Wizytówką sandomierskiej Starówki jest Rynek z gotycko-renesansowym ratuszem (fot. 3) oraz usytuowanymi wokół niego kamienicami (Na uwagę zasługuje zwłaszcza pierzeja zachodnia z Kamienicą Oleśnickich i Konwiktem Boboli z dzisiejszą Zbrojownią Chorągwi Rycerstwa Ziemi Sandomierskiej) oraz wschodnia z Domem Greka Kojszora (fot. 4, 5). Wyróżnia się również narożny dom Mikołaja Gomułki oraz kamienica Węgra Lazarczyka (znana jako Kamienica pod Ciżemką). Budynek tzw. Kordegardy (siedziba Oddziału Ziemi Sandomierskiej PTTK) oddziela Rynek od Małego Rynku, który stanowi współcześnie plac przeznaczony na funkcje handlowe, w tym stragany z pamiątkami oraz małą gastronomię. Spośród ulic wychodzących z Rynku, główną rolę odgrywa ulica Opatowska (fot. 6), łącząca go z Bramą Opatowską (pozostałość po pierwotnych murach miejskich). Ulica Zamkowa łączy centrum Starego Miasta z Zamkiem (obecnie siedziba Muzeum Okręgowego) (fot. 7), a dalej ze wzgórzami staromiejskimi (w tym kościołem św. Jakuba oraz Wąwozem św. Królowej Jadwigi) (fot. 8). Ulica Mariacka prowadzi z Rynku w kierunku „kościelnej” części miasta z katedrą, pałacem biskupim oraz innymi budynkami administracji kościelnej. Szczególnie ważnym obiektem w tej części miasta jest gotycki Dom Długosza (fot. 9), mieszczący obecnie Muzeum Diecezjalne. Sąsiaduje z nim budynek pojezuickiego Collegium Gostomianum, będący największym kubaturowo obiektem leżącym bezpośrednio na skarpie, co czyni go wyraźną dominantą w sylwecie miasta obserwowanej od strony Wisły (fot. 1). Wschodnią część Starego Miasta (ul. Żydowska) zajmowała dzielnica żydowska, po której pozostał budynek dawnej synagogi z XVII w. (obecnie Archiwum Państwowe) oraz dom kahału z XVIII w.

W mieście zachowało się kilka dworów szlacheckich, których część współcześnie pełni funkcje noclegowe, np. Dworek Skorupskich (obiekt noclegowy „Dworek Ojca Mateusza”), Dworek Stróżyńskich (Hotel „Sarmata”), Dwór Karpińskich (pensjonat).

\section{STARE MIASTO JAKO MIEJSCE ORGANIZACJI IMPREZ PLENEROWYCH}

Stare Miasto w Sandomierzu jest miejscem wielu imprez o charakterze kulturalnym. Zabytki Sandomierza, a szczególnie sandomierski rynek stanowi wyjątkową oprawę dla wydarzeń związanych z dziejami miasta, regionu i kraju. Pod tym względem wyróżnia się przede wszystkim Jarmark Jagielloński i towarzyszący mu turniej rycerski. Dwudniowa impreza odbywa się w lipcowy weekend i rozpoczyna inscenizacją aktu koronacji żony Władysława Jagiełly, wojewodzianki sandomierskiej Elżbiety Granowskiej, na królową Polski. Podczas imprezy wystawcy z całego kraju prezentują wyroby artystyczne i kulinarne. Na sandomierskich błoniach rozgrywany jest turniej rycerski oraz odbywają się pokazy średniowiecznego wojska. Stałym punktem są pokazy tańca dworskiego oraz uroczyste parady. Organizowane są gry i zabawy dla uczestników w różnym wieku. Jarmark Jagielloński wpisuje się w tradycję wydarzeń kulturalnych i artystycznych odbywających się w miastach leżących na tzw. Szlaku Jagiellońskim (Via Jagiellonica), łączącym Kraków z Wilnem.

\section{STARE MIASTO JAKO PLENER FILMOWY - CASUS SERIALU TELEWIZYJNEGO „OJCIEC MATEUSZ”}

Współcześnie jednym z symboli miasta stała się postać księdza Mateusza Żmigrodzkiego, tytułowego bohatera serialu telewizyjnego „Ojciec Mateusz”, kręconego od 2008 r. przez Telewizję Polską w oparciu o włoski pierwowzór „Don Matteo”. O wyborze Sandomierza spośród innych miast-kandydatur zadecydował m.in. historyczny charakter miasta bogatego w zabytki, co stanowi bezpośrednie nawiązanie do włoskiego pierwowzoru - miasteczka Gubbio. Ważną rolę odegrała także przychylność i życzliwość zarówno administracji miasta, jak i władz duchownych (Diecezja Sandomierska). Film realizowany był zarówno w samym Sandomierzu oraz jego okolicach, jak i na mocy porozumień podpisanych przez Telewizję Polską i ROT Województwa Świętokrzyskiego także w innych miejscach regionu, m.in. w Busku-Zdroju, Opatowie, Wąchocku czy Kielcach (SZPARA, MUSZ 2016). W konsekwencji serial odegrał kluczową rolę w promocji walorów turystycznych miasta oraz kreowaniu jego wizerunku jako przyjemnego i przychylnego dla turystów miejsca (fot. 10).

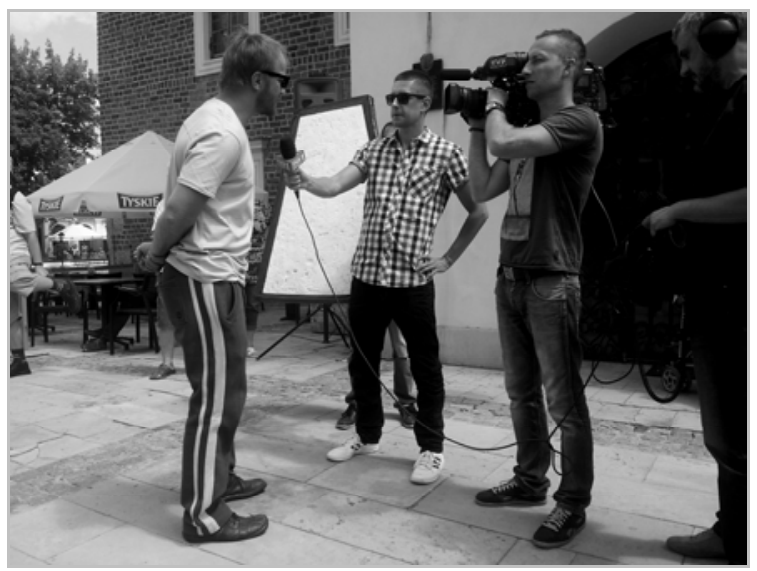

Fot. 10. Ekipa serialu „Ojciec Mateusz” podczas promocji gry „Ojciec Mateusz - tajemnicze zagadki Sandomierza” 2 lipca 2014 r. na Rynku w Sandomierzu (fot. R. Faracik) 
W 2015 r. na ekrany kin trafił film pt. „Ziarno prawdy", będący adaptacją powieści kryminalnej Zygmunta Miłoszewskiego pod tym samym tytułem. Akcja filmu rozgrywa się w Sandomierzu, a miasto stało się plenerem przy jego realizacji.

\section{BAZA NOCLEGOWA I JEJ PRZESTRZENNE ZRÓŻNICOWANIE}

Baza noclegowa stanowi podstawowy element infrastruktury turystycznej, a jej wielkość i struktura jest wyznacznikiem stanu rozwoju funkcji turystycznej. Osobne zagadnienie stanowi przestrzenne zróżnicowanie obiektów noclegowych. Jeżeli sam rozwój bazy noclegowej Sandomierza jest uwarunkowany wysokiej rangi walorami turystycznymi oraz promocją miasta, to lokalizacja konkretnych obiektów w jego przestrzeni jest wypadkową wielu czynników.

W wyniku inwentaryzacji (kartowanie w terenie oraz kwerenda źródeł internetowych) przeprowadzonej w 2016 r. zlokalizowano 107 obiektów noclegowych o łącznej pojemności 2532 miejsc noclegowych, z czego około $90 \%$ to miejsca w obiektach całorocznych. Największą pojemnością (powyżej 100 miejsc noclegowych) odznaczały się dwa hotele (Mały Rzym***, Sarmata $^{* * *}$ ) i motel z pensjonatem (Motel Królowej Jadwigi) oraz dwa obiekty noclegowe o charakterze wycieczkowym (Salus i Bursa Szkolna). Sezonowy charakter ma Kemping Browarny (o łącznej pojemności 200 osób), dysponujący także całorocznymi miejscami noclegowymi w pokojach.

Analizując rozkład przestrzenny bazy noclegowej w Sandomierzu można wydzielić obszary jej koncentracji (rys. 3, oznaczenia A-G):

A - obszar obejmujący Stare Miasto wraz z zamkiem oraz sąsiadującym $\mathrm{z}$ nim terenem wcześniejszego grodu (po okolice kościoła św. Jakuba). Lokalizacja obiektów wiąże się $\mathrm{z}$ bezpośrednim sąsiedztwem zabytkowej zabudowy, a ich różnorodność dotyczy zarówno typu (hotele, pokoje gościnne, pensjonaty oraz inne obiekty zakwaterowania zbiorowego), jak i standardu oferowanych usług. Część $\mathrm{z}$ nich znajduje się $\mathrm{w}$ oryginalnych zabytkowych wnętrzach.

B - rejon ul. Zawichojskiej, od Bramy Opatowskiej po ulicę Żwirki i Wigury. Pokrywa się częściowo z zasięgiem historycznego Przedmieścia Zawichojskiego. Obiekty koncentrują się wzdłuż głównej trasy dojazdowej w rejon Starego Miasta od strony Krakowa i Tarnobrzega. Obejmuje obszar na wschód od ul. Zawichojskiej po skarpę. Znajdują się tu zarówno pokoje gościnne, jak i dwa duże obiekty noclegowe
- hotel Sarmata oraz Dom Turysty PTTK. Wyróżnia się dobrą dostępnością i bliskością zespołu staromiejskiego.

C - rejon ul. Mickiewicza i Żeromskiego, od Bramy Opatowskiej i klasztoru benedyktynek po ul. T. Kościuszki wraz z okolicami klasztoru reformatów i Parku Miejskiego. Obszar ten bezpośrednio sąsiaduje ze Starym Miastem i obejmuje historyczne Przedmieście Opatowskie. Odznacza się dogodnym położeniem w stosunku do zabytkowego centrum, jak i bezpośrednim sąsiedztwem cennych zespołów architektonicznych oraz terenów zielonych.

D - rejon ul. 11 Listopada, od ul. A. Mickiewicza po ul. Okrzei. Obszar ten od zachodu sąsiaduje $z$ jednostką wojskową i obejmuje głównie dzielnicę domów jednorodzinnych położoną w obrębie ul. 11 Listopada oraz Wojska Polskiego (wraz z przecznicami) - w rejonie skrzyżowania tych ulic znajduje się dworzec autobusowy. Oprócz pokoi gościnnych oferowanych w domach, znajduje się tutaj hotel Mały Rzym oraz Bursa Szkolna oferująca noclegi dla grup wycieczkowych.

E - osiedle domów jednorodzinnych między ul. Słoneczną a Rokitek. W domach oferowane są pokoje gościnne i mieszkania do wynajęcia. Komunikację ze Starym Miastem zapewnia ul. Staromiejska, wiodąca od osiedla, koło kościoła św. Piotra ku kościołowi św. Jakuba i Zamkowi. Obszar ten oddzielony jest od Starego Miasta głębokim lessowym wąwozem.

F - Gołębice - teren położony wzdłuż dróg krajowych 77 i 79 (w granicach Sandomierza ul. E. Kwiatkowskiego) oraz ul. Różanej. Ma charakter głównie tranzytowy.

G - prawobrzeżna część Sandomierza związana m.in. z hutą szkła oraz innymi zakładami (południowa część obszaru) oraz zabudową jednorodzinną w obrębie dawnych wsi. W części składowo-przemysłowej oraz osiedlowej (rejon ul. Portowej) funkcjonują obiekty zakwaterowania zbiorowego ukierunkowane na obsługe grup wycieczkowych. Obecnie obserwuje się proces powstawania nowych obiektów przy ul. Lwowskiej (droga krajowa 77). W Ostrówku i Nadbrzeziu oferowane są pokoje gościnne i mieszkania w prywatnych domach. Rozwój funkcji turystycznej w tej części miasta wiąże się z transformacją funkcji przemysłowej zachodzącą od lat 90. XX w.

Oddzielną grupę stanowią obiekty noclegowe związane z funkcjonującymi w obrębie miasta gospodarstwami rolnymi i winnicami oraz innymi domostwami na obszarach o cechach typowo rolniczych (pó1nocna i północno-wschodnia część miasta). Znajdują się tam zarówno gospodarstwa agroturystyczne, jak i obiekty o charakterze pensjonatowym. Do grupy tej można także zaliczyć zlokalizowane w Mokoszynie: internat przy Zespole Szkół Centrum Kształcenia Rolniczego im. Ziemi Sandomierskiej oraz obiekt noclegowy przy Ośrodku Doradztwa Rolniczego. 


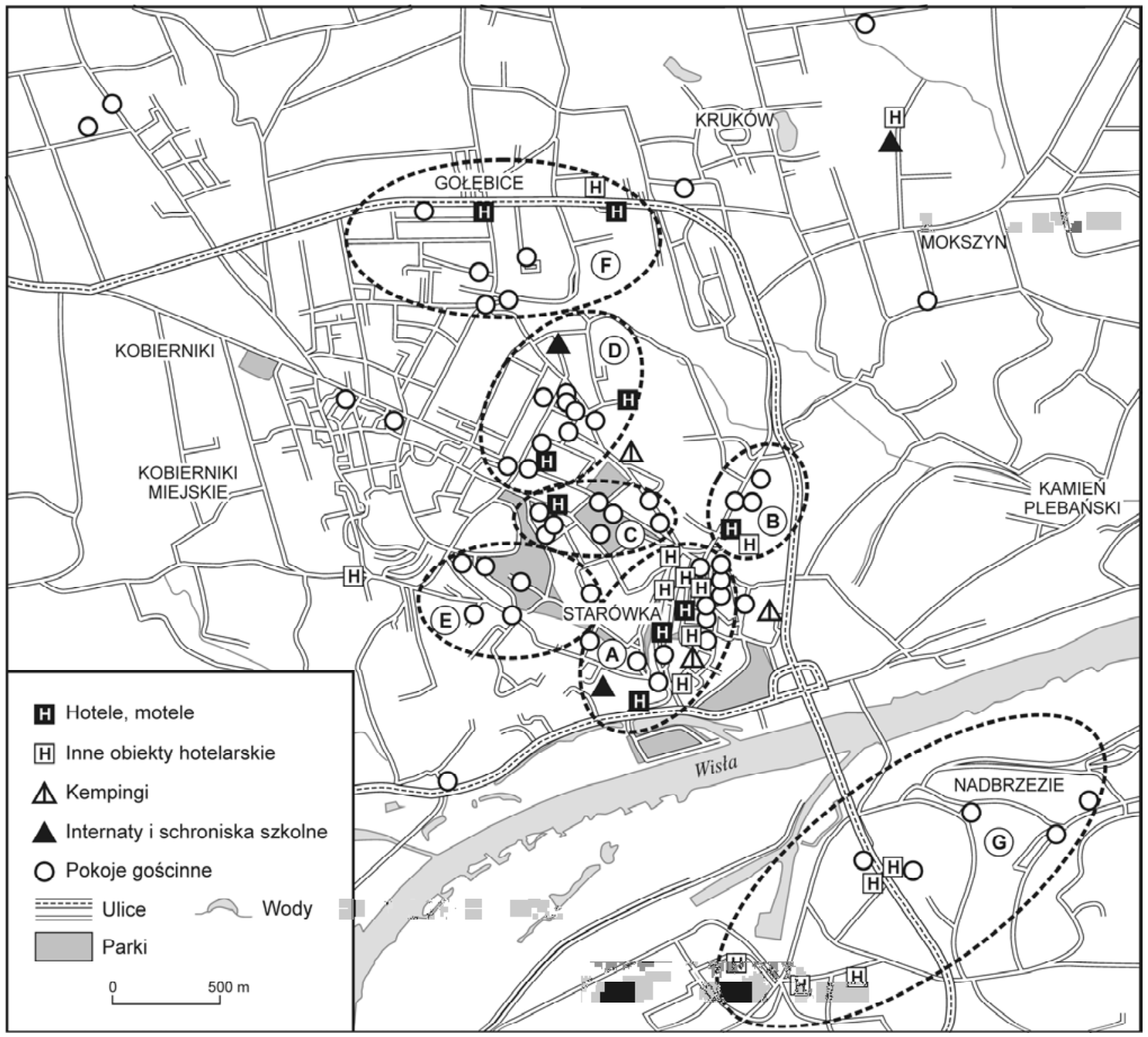

Rys. 3. Obiekty noclegowe w Sandomierzu i obszary ich koncentracji (A-G - objaśnienia w tekście)

Źródło: opracowanie własne (podkład z www.google.pl/maps)

Popularnym typem zakwaterowania są prywatne mieszkania i pokoje wynajmowane turystom, nie tylko w domach jednorodzinnych, ale także $\mathrm{w}$ obrębie budownictwa wielokondygnacyjnego, w tym osiedli mieszkaniowych. Udział tego typu miejsc noclegowych w ogólnej liczbie miejsc noclegowych Sandomierza można szacować na $10-15 \%$. Do użyt$\mathrm{ku}$ oddawane są także mieszkania typu apartamentowego $\mathrm{w}$ nowo powstających inwestycjach lub $w$ remontowanych $i$ adaptowanych na cele mieszkaniowe obiektach zabytkowych w obrębie Starego Miasta.

\section{RUCH TURYSTYCZNY W OBRĘBIE STAREGO MIASTA}

Problem z pozyskaniem wiarygodnych danych dotyczących ruchu turystycznego jest jedną z podstawowych barier $w$ charakterystyce i ocenie całego zjawiska turystyki. Oficjalne dane statystyczne (oparte na meldunkach w obiektów noclegowych) obarczone są dużym błędem. Pełnego obrazu zjawiska nie dają także dane dotyczące frekwencji $w$ atrakcjach turystycznych (sprzedane/ wydane bilety). W celu oszacowania wielkości ruchu turystycznego w Sandomierzu prze- 
prowadzono badanie ${ }^{1}$ frekwencji odwiedzających w charakterystycznych punktach Starego Miasta:

- przy studni na Rynku;

- przy Domu Długosza;

- przed bramą wejściową na zamek;

- przed wejściem do kościoła św. Jakuba oraz

- przy wylocie Wąwozu św. Królowej Jadwigi (dolne wejście).

Badanie przeprowadzono $\mathrm{w}$ dniach: 2 lipca $2014 \mathrm{r}$. (środa), 4 lipca 2014 r. (piątek) oraz 16 maja 2015 r. (sobota), w godzinach 8.00-17.00. Wszystkie te dni odznaczały się słoneczną pogodą, sprzyjającą spacerom i zwiedzaniu miasta. Przyjmując, że wizyta na Rynku jest obowiązkowym punkiem programu każdego turysty odwiedzającego Sandomierz, można stwierdzić, że Stare Miasto odwiedziło w kolejnych dniach pomiaru: 2,4 tys. osób 2 lipca 2014 r. ; 5,1 tys. - 4 lipca 2014 oraz 2,2 tys. turystów - 16 maja 2015 r. (tab. 1). Charakterystycznym zjawiskiem jest wyraźny spadek frekwencji turystów w punktach oddalonych od Rynku. Pomimo stosunkowo niewielkich rozmiarów sandomierskiego Starego Miasta, znaczna część turystów pozostaje w obrębie samego rynku, gdzie zlokalizowane są główne atrakcje turystyczne - Podziemna Trasa Turystyczna, Zbrojownia, a od 2017 r. wystawa "Świat Ojca Mateusza”. Dużą atrakcję turystyczną stanowi Brama Opatowska (punkt widokowy).

Tab. 1. Frekwencja w wybranych punktach Starego Miasta w Sandomierzu w latach 2014-2015

\begin{tabular}{|l|r|r|r|}
\hline \multirow{2}{*}{\multicolumn{1}{|c|}{ Miejsce pomiaru }} & \multicolumn{3}{c|}{ Liczba osób } \\
\cline { 2 - 4 } & $\begin{array}{r}2 \text { VII } \\
2014\end{array}$ & $\begin{array}{r}4 \text { VII } \\
2014\end{array}$ & $\begin{array}{r}16 \text { V } \\
2015\end{array}$ \\
\hline Rynek (studnia) & 2398 & 5073 & 2205 \\
\hline Przy Domu Długosza & 893 & 1156 & 1615 \\
\hline Wejście na zamek & 614 & 565 & 1015 \\
\hline Wejście do kościoła św. Jakuba & 498 & 765 & b.d. \\
\hline $\begin{array}{l}\text { Wąwóz Królowej Jadwigi } \\
\text { (dolne wejście) }\end{array}$ & 219 & 339 & 383 \\
\hline
\end{tabular}

b.d. - Brak danych.

Źródło: opracowanie własne.

Na fakt wzrostu liczby turystów odwiedzających miasto od 2008 r. zwracają uwagę K. SZPARA i R. MUSZ (2016). Według tych autorów w dużej mierze jest to efekt promocji Sandomierza poprzez emisję serialu "Ojciec Mateusz". Widoczne jest to m.in. we frekwencji w głównych atrakcjach turystycznych miasta. W latach 2008-2011 liczba zwiedzających Podziemną Trasę Turystyczną wzrosła o ponad 70 \% (z nieco ponad 80 tys. w 2008 do ponad 137 tys. w 2011 r.), a Bramę Opatowską o ponad 87\% (z blisko 68 tys. w 2008 r. do ponad 127 tys. w 2011). Zwiększyła się także wyraźnie liczba miejsc noclegowych oraz korzystających z noclegów.
W ostatnich latach wyraźnie wzrastała także liczba odwiedzających miejscowe muzea (funkcjonują dwa - Muzeum Diecezjalne i Muzeum Okręgowe oraz oddział Muzeum Polskiego Ruchu Ludowego w Warszawie). W 2016 r. zwiedziło je łącznie 95,9 tys. osób (dla porównania, w 2012 było to 80,2 tys., a w 2014 - 72,2 tys. - dane wg Banku Danych Lokalnych).

Przeprowadzone badania sondażowe na próbie 211 turystów odwiedzających Sandomierz (95 mężczyzn oraz 116 kobiet; wiek respondentów: poniżej 25 lat - 33 osoby; 26-50 lat - 120 osób; powyżej 50 lat - 38 osób) w dniach 1-4 lipca 2014 r. wykazały, że serial telewizyjny i postać Ojca Mateusza należy do głównych skojarzeń z miastem (123 odpowiedzi, co stanowi 58,3\%), przy czym serial jako jeden z powodów wyboru Sandomierza na miejsce przyjazdu deklarowały 32 osoby (15,2\%), a odwiedzanie miejsc związanych z filmem 11 osób (5,2%) (FARACIK i in. 2015).

\section{ZAKOŃCZENIE}

Sandomierz należy do najlepiej zachowanych i najciekawszych zespołów zabytkowych w Polsce, dzięki czemu stał się ważnym ośrodkiem turystyki poznawczej. Mimo że obecnie kojarzony jest zazwyczaj z serialem "Ojciec Mateusz" i ukazywany jako przykład rozwoju turystyki filmowej w Polsce, władze miasta starają się promować także inne walory, często unikatowe. Szczególnie interesujący pod tym względem jest projekt „Sandomierz światową stolicą krzemienia pasiastego", w ramach którego w mieście organizowane są imprezy, konkursy i warsztaty promujące krzemień pasiasty jako surowiec jubilerski, co jest nawiązaniem do tej tradycji zapoczątkowanej w końcu lat 70. XX w. przez artystę Cezarego Łutowicza - niekwestionowany autorytet w tej dziedzinie (WóDZ, red. 2008, 2009). Innym przykładem jest promocja Sandomierza jako ośrodka ważnego regionu sadowniczego i ogrodniczego, do czego nawiązuje powołanie do życia Sandomierskiego Szlaku Jabłkowego, oferującego kilka pakietów turystycznych. Jednym z nich jest Szlak Winiarski, będący jedną z propozycji rozwijającej się w samym mieście i jego okolicach oferty enoturystycznej (KAPŁAN 2014). Sandomierz uchodzi także za polską „stolicę” brzoskwiń i moreli (KĘSIK 1998).

Tysiącletnia tradycja Sandomierza jako ośrodka życia religijnego widoczna jest współcześnie w krajobrazie sakralnym miasta oraz stanowi szczególnego rodzaju genius loci tego miejsca. Potwierdziła to m.in. wizyta papieska w czerwcu 1999 r., a Sandomierz już od kilku wieków jest celem pielgrzymek wiernych.

We wzroście ragi Sandomierza jako rozwijającego się ośrodka ruchu turystycznego upatrywać można w przyszłości czynnika hamującego postępującą depo- 
pulację miasta. Konieczna jest dalsza dywersyfikacja oferty turystycznej i powiązanie jej z innymi atrakcjami w sąsiedztwie. Oprócz obiektów zabytkowych (m.in. Opatów, Baranów Sandomierski, Koprzywnica, Kurozwęki, ruiny zamku Krzyżtopór w Ujeździe) jedną z propozycji jest zbiornik wodny w Tarnobrzegu (o powierzchno około 500 ha), powstały na bazie dawnej odkrywkowej kopalni siarki, którego proces zagospodarowywania rozpoczął się.

\section{PRZYPIS}

${ }^{1}$ Badania przeprowadzono $\mathrm{w}$ ramach ćwiczeń terenowych z geografii społeczno-ekonomicznej (2014) oraz ćwiczeń terenowych specjalizacyjnych z geografii turyzmu (2015). Brali w nich udział studenci geografii z Instytutu Geografii i Gospodarki Przestrzennej UJ pod opieką autora.

\section{BIBLIOGRAFIA}

ASHWORTH G.J., 1993, Heritage planning: An approach to managing historic cities, [w:] Z. Zuziak (red.), Managing historic cities, Międzynarodowe Centrum Kultury, Kraków, s. 27-47.

ASHWORTH G.J., TUNBRIDGE J.E., 1990, The tourist-historic city, Belhaven Press, London.

CZARNECKI R., 1996, Wyżyna Sandomierska. Część wschodnia, t. I. Komponenty krajobrazu geograficznego, nakład aut.

FARACIK R., KUREK W., MIKA M., PAWLUSIŃSKI R., 2015, "Stare” $i$ "nowe" wartości w turystyce miejskiej. Zarys problematyki, [w:] P. Trzepacz, J. Więcław-Michniewska, A. Kołoś (red.), Miasto w badaniach geografów, t. 1., Instytut Geografii i Gospodarki Przestrzennej, Uniwersytet Jagielloński, Kraków, s. 121-133.
FLOREK M., 2005, Sandomierski ośrodek grodowo-miejski w średniowieczu, Wyd. Naukowe Semper, Warszawa.

KALINOWSKI W., 1986, Sandomierz, [w:] W. Kalinowski (red.), Zabytki urbanistyki, architektury w Polsce. Odbudowa i konserwacja, t. 1. Miasta historyczne, Arkady, Warszawa, s. 421-436.

KALINOWSKI W, LALIK T., PRZYPKOWSKI T., RUTKOWSKI H., TRAWKOWSKI S., 1956, Sandomierz. Budownictwo i architektura, Warszawa.

KAPŁAN M., 2014, Szlakiem sandomierskich winnic, [w:] J. Suszyna (ed.), Powrót do tradycji winiarskich ziemi sandomierskiej, Towarzystwo Naukowe Sandomierskie, Sandomierz, s. 102-112.

KĘSIK T., 1998, Uprawa moreli i brzoskwiń jako osobliwość krajobrazu ziemi sandomierskiej, [w:] T. Puszkara (red.), Osobliwości przyrody ziemi sandomierskiej, Towarzystwo Naukowe Sandomierskie, Sandomierz, s. 30-38.

MiKOŚ T., CHMURA J., TAJDUŚ A., 2013, Górnicze metody ratowania zabytkowych dzielnic staromiejskich, Wyd. Akademii Górniczo-Hutniczej, Kraków.

MYJAK J., 2013 (ed.), Zarys dziejów prawobrzeżnego Sandomierza, Myjakpress, Sandomierz.

PAEYS S., WĘGOREK T., 1998, Wąwozy lessowe jako osobliwość okolic Sandomierza, [w:] T. Puszkara (red.), Osobliwości przyrody Ziemi Sandomierskiej, Towarzystwo Naukowe Sandomierskie, Sandomierz, s. 21-29.

SZPARA K., MUSZ R., 2016, Turystyka filmowa w Sandomierzu, „Prace Geograficzne”, 145, s. 31-45, DOI: 10.4467/20833113 PG.16.011.5400.

WÓDZ B. (red.), 2008, 35 lat krzemienia pasiastego w biżuterii, Muzeum Okręgowe w Sandomierzu, Sandomierz.

WóDZ B., 2009, Sandomierski kamień optymizmu, [w:] P. Król (red.), Historia krzemienia, Muzeum Narodowe w Kielcach, Kielce, s. 104-110.

Artykuł wpłynął: 17 października $2017 \mathrm{r}$ Zaakceptowano: 10 grudnia $2017 \mathrm{r}$. 